\title{
Dynamic Evaluation of Heat Thefts Due to Different Thermal Performances and Operations between Adjacent Dwellings
}

\author{
Laura Canale ${ }^{1,2} \mathbb{D}$, Vittoria Battaglia ${ }^{1}$, Giorgio Ficco ${ }^{2}$, Giovanni Puglisi ${ }^{3}$ and Marco Dell'Isola ${ }^{2, *}$ \\ 1 Dipartimento di Ingegneria, Università degli Studi di Napoli “Parthenope", 80143 Napoli, Italy; \\ l.canale@unicas.it (L.C.); vittoria.battaglia@uniparthenope.it (V.B.) \\ 2 Dipartimento di Ingegneria Civile e Meccanica, Università degli Studi di Cassino e del Lazio Meridionale, \\ Via G. Marconi 10, 03043 Cassino, Italy; ficco@unicas.it \\ 3 ENEA Centro della Casaccia, Via Anguillarese 301, 00123 Rome, Italy; giovanni.puglisi@enea.it \\ * Correspondence: dellisola@unicas.it
}

Received: 2 March 2020; Accepted: 30 March 2020; Published: 2 April 2020

\begin{abstract}
Apartment position and operation within buildings play a significant role on energy consumption and also on perceived thermal comfort. Dwellings with favorable positions can have significant benefit, also when heated for a limited number of hours, if compared to apartments located in disadvantaged positions (i.e., upper or lower floors or north-oriented). This may be the cause of debates, especially in buildings with central heating, when heat costs are shared among tenants by means of sub-metering systems. In this paper, authors address this issue by studying the "heat thefts" phenomenon in dynamic conditions in a low-insulated building, when the heating system is used unevenly by the tenants (i.e., with different temperatures and/or use). To this end, a social housing building located in Mediterranean climate, where daily temperature excursions and solar heat gains enhance the dynamics of the heat flows, has been chosen as the case-study. The real operation of the building has been simulated in different operational scenarios and the model has been validated against energy consumption data collected experimentally. Results confirm that special allocation and or/compensation strategies should be taken in heat costs allocation in order to avoid accentuating situations of inequalities, especially in low-insulated and/or occasionally heated buildings.
\end{abstract}

Keywords: stolen heat; energy efficiency; heat metering; heat accounting; dynamic simulation; social housing; building simulation; heat cost allocators; thermostatic radiator valves

\section{Introduction}

As well known, in recent years targeting energy efficiency in residential buildings has become a key issue for the European Union (EU) which has committed itself to cut its greenhouse gas emissions to $80-95 \%$ below 1990 levels by 2050 [1]. Indeed, buildings are responsible for $36 \%$ of global final energy consumption in Europe and for nearly $40 \%$ of total direct and indirect $\mathrm{CO}_{2}$ emissions [2], of which about $70 \%$ is due to heating the existing building stock. For this reason, in 2012 the EU issued the so-called "Energy Efficiency Directive" (EED) [3] amended in 2018 as part of the "Clean energy for all Europeans package", establishing a set of binding measures to help the EU reach its energy efficiency target. In particular, Article 9 highlights the need to ensure that final customers are provided with meters that accurately reflect their actual energy consumption and set as mandatory the installation of individual meters in buildings supplied from a central source, whether sub-metering is cost-efficient or the related costs are proportionate in relation to the potential energy savings [4]. In this way, end-users should be aware, and at the same time responsible, of their energy consumption. 
This obligation has led to a number of issues related to a fair billing service [5,6]. Indeed, fair and transparent heat cost allocation for heating/cooling/hot water costs is a difficult subject. In fact, especially in old and existing buildings, the lack of insulation of walls can generate heat transfers between adjacent apartments, when these are heated at different set-point temperatures (the so-called "stolen heat" or "heat thefts"), being the cause of involuntary over-consumptions for dwelling surrounded by numerous unheated or occasionally heated apartments. In this sense, a number of authors addressed the problem, with some [7-9] from the perspective of heat cost allocation, others [10-13] analyzing the phenomenon in a quantitative manner.

Within the first group, Liu et al. [7] presented an alternative method for allocating heat costs in multi-apartment buildings based on measuring the on-off ratio of the thermostatic valves on the radiators. A cost-efficient method was developed for reallocation of heating costs based on heat transfers between the adjacent apartments by Siggelsten [14] which was then further developed by Michnikowski [9] basing on the data of the average indoor temperature provided by special heat cost allocators.

Among the second group, Gafsi and Lefebvre [10] demonstrated that an apartment can gain up to $90 \%$ of heat from adjacent apartments and highlighted the complexity of the phenomenon and the large number of influence factors. Pakanen and Karjalainen [11] proposed a method for estimating static heat flows between adjacent rooms in a hypothetical environment simulated using TRNSYS software. Lukić et al. [12] showed that, in fully insulated buildings, an unheated dwelling can steal about $80 \%$ of its total energy need from the surrounding apartments, by simulating a real building using EnergyPlus simulation software. In [13], an energy simulation is adopted to calculate the heat transfer proportion with the validation of on-site measurement, showing an unexpected amount of adjacent room heat transfer up $70 \%$ of the total heating load.

That said, it is clear that apartment location and operation can play a significant role on its energy consumption. In fact, depending on the type of building, dwellings with favorable positions, such as those with a high interior to total wall surface ratio, the ones south oriented, etc., can have significant benefit by gaining heat from surrounding dwellings, if compared to apartments located in more disadvantaged positions.

In this paper, the issue of heat thefts has been investigated by performing a dynamic simulation on a real case-study represented by a social housing building supplied by a centralized natural gas boiler, using TRNSYS simulation software. To this end, the real operation of the building (base scenario) has been simulated and the model has been validated against real energy consumption data collected by means of direct and indirect heat metering systems installed. Thanks to the validated model, it was possible to simulate two additional scenarios (scenarios a and b) in which two apartments representative of the most and the least favored positions were considered, individually, unheated.

The main aim of this work is to analyze different scenarios of building operation, with particular reference to the effects of heat transfers between adjacent dwellings in terms of energy consumption and heat cost allocation under uneven use of the heating system (in terms of occupancy of the dwellings and different set-point temperatures). The dynamic of heat transfers has been simulated with reference to an Italian building with low thermal energy performances and in a Mediterranean climate, to highlight the differences with other existing studies. Thus, the novelty of this work relies on the fact that the authors focused on the issue of heat thefts in buildings from the point of view of the allocation of heating costs among the dwelling units. This allowed for greater understanding of the dynamic behavior of the heat fluxes in relation to the single apartments rather than the entire building, especially considering that the Mediterranean climatic conditions may enhance the dynamics of the heat flows due to temperature excursions and solar heat gains during the day.

The main findings of the analysis revealed dynamic effects of "inversion" of the heat transfers between adjacent apartments, that would not have been evident in static conditions, and that should be carefully taken into account for heat cost allocation in social housing context. The results may be particularly useful because the case-study is representative of the Italian building stock in terms 
of constructive characteristics and heating plant and also because the influence of solar heat gains in Mediterranean climate conditions on the heat theft phenomenon is highlighted through the dynamic simulation.

\section{Materials and Methods}

\subsection{The Building Case-Study}

The object of this study is represented by a low-insulated building located in a Mediterranean climate. To this end, a social housing building located in the province of Frosinone, Italy has been chosen as the subject of this study and simulated under both the hypothesis of uneven operational temperatures and occasional heating. In particular, the building has been studied under actual operational conditions, meaning that real set-point temperatures and operation hours of the heating system effectively set by the users were employed for the simulation. Specifically, the set-point temperatures of the fully-occupied building simulation varied between $18.6^{\circ} \mathrm{C}$ and $22.1{ }^{\circ} \mathrm{C}$ as a function of the given end-user, while the operation hours were equal for all the dwellings (i.e., from 6 to 8 a.m. and from 15 to 22 p.m. according to the real settings of the centralized heating plant). The outdoor climatic conditions are those typical of the climatic zone in which the building is located and vary between $\left(23.2 /-2.1^{\circ} \mathrm{C}\right)$ in the simulation period.

The building was built in 1979 by ATER, the Italian Territorial Agency for Social Housing Buildings. The hydronic heating system consists on a central natural gas boiler with a maximum power of $152 \mathrm{~kW}$, located in the ground floor, with uninsulated distribution pipes running mainly in the outer walls in vertical configuration [15] and emission terminals consisting of traditional cast iron radiators.

Nine dwellings are arranged in two blocks each of which with three floors. The first, consisting of three dwellings, is located above the front porch (type C); the second, located above the garages, is made up of six dwellings (two on each floor), three north-west oriented (type B) and three south-west oriented (type A). Figure 1a,b shows, respectively, the cross section of the building and the plant scheme of a representative floor, while Figure 2 shows a picture of the investigated building.

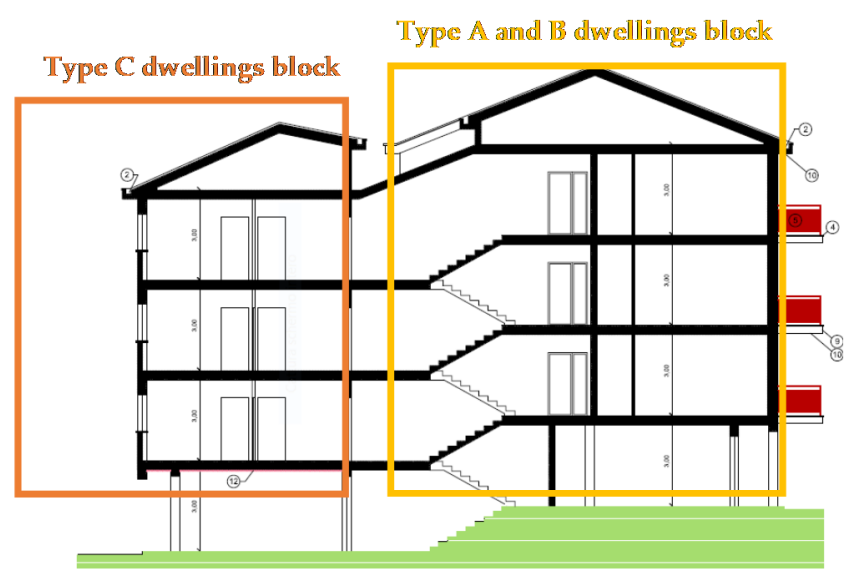

(a)

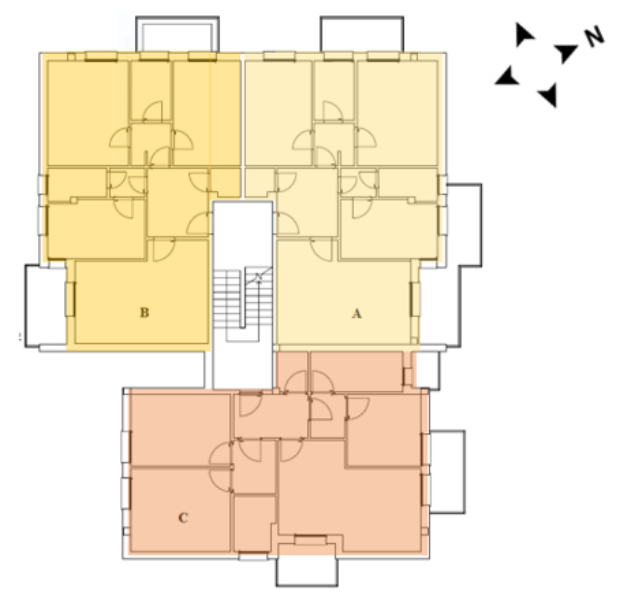

(b)

Figure 1. (a) Cross-section of the building case-study; (b) plant scheme of a representative floor.

Dwellings of types A and B have a net floor area of about $79 \mathrm{~m}^{2}$, while type C ones have a net floor area of about $86 \mathrm{~m}^{2}$. The net interstorey height is about $2.7 \mathrm{~m}$.

It is underlined that almost all the walking surface of the first floor, which is located above the garages and the porch, is exposed to the external environment (the garages have open doors), as well as almost all the ceiling of the last floor faces the unheated attic. 


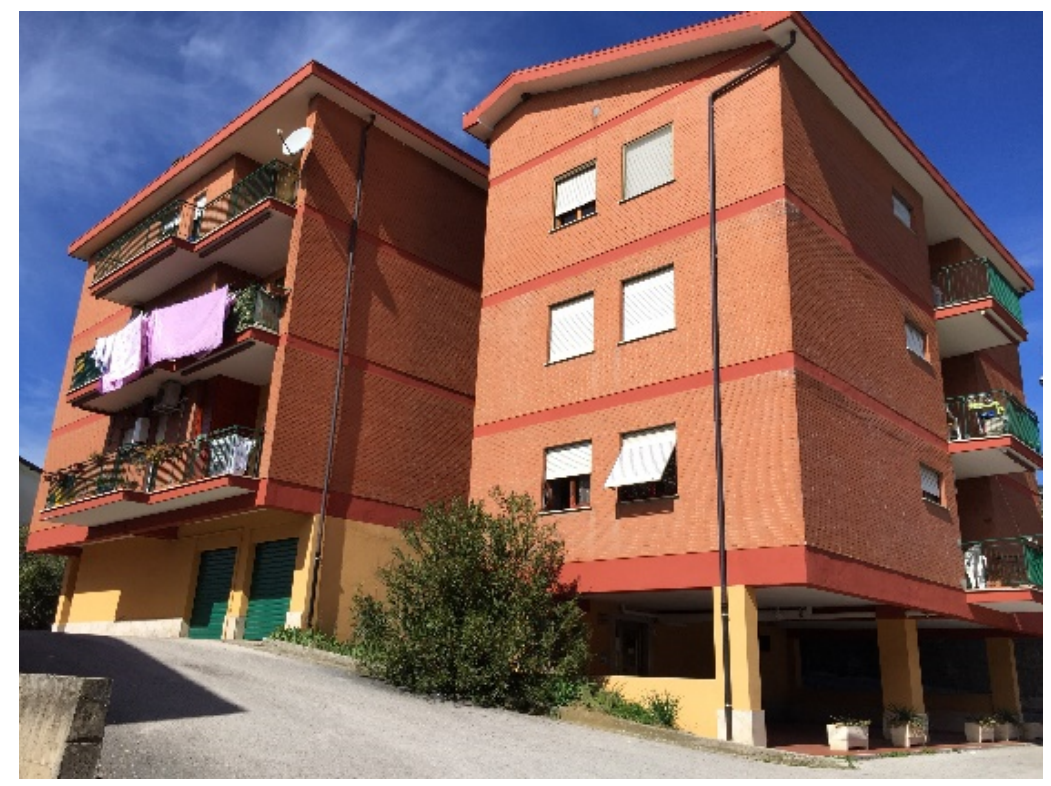

Figure 2. Picture of the building case-study.

The main thermal and physical characteristics of the investigated building, collected through on-site inspections and document review, are listed in Table 1. A distinction has been made between two different types of floors, since the outer floor of the dwelling located on the porch has undergone a thermal insulation with the addition of an external layer of expanded polystyrene $0.05 \mathrm{~m}$ thick, while the outer floor of the other apartments located at the first floor did not.

Table 1. Main constructive characteristics of the investigated building.

\begin{tabular}{|c|c|c|c|}
\hline Building Element & $\begin{array}{c}\text { Layers } \\
\text { (from Inside to Outside) }\end{array}$ & Thickness [m] & Thermal Transmittance $\left[\mathrm{W} /\left(\mathrm{m}^{2} \mathrm{~K}\right)\right]$ \\
\hline \multirow{4}{*}{ Outer ceiling } & Lime/gypsum plaster & 0.020 & \multirow{4}{*}{2.68} \\
\hline & Concrete & 0.200 & \\
\hline & Waterproofing layer & 0.004 & \\
\hline & Tiles & 0.015 & \\
\hline \multirow{5}{*}{ Outer floor (porch apt.) } & Floor tiles & 0.010 & \multirow{5}{*}{0.49} \\
\hline & Lean concrete & 0.050 & \\
\hline & Hollow core concrete & 0.180 & \\
\hline & Expanded polystyrene & 0.050 & \\
\hline & Lime/gypsum plaster & 0.020 & \\
\hline \multirow{4}{*}{ Outer vertical walls } & Lime/gypsum plaster & 0.020 & \multirow{4}{*}{1.25} \\
\hline & Hollow clay bricks & 0.100 & \\
\hline & Air Gap & 0.080 & \\
\hline & Hollow concrete bricks & 0.100 & \\
\hline \multirow{3}{*}{ Inner vertical walls } & Lime/gypsum plaster & 0.010 & \multirow{3}{*}{2.10} \\
\hline & Hollow clay bricks & 0.100 & \\
\hline & Lime/gypsum plaster & 0.010 & \\
\hline \multirow{4}{*}{ Inner ceiling and all other floors } & Floor tiles & 0.010 & \multirow{4}{*}{1.25} \\
\hline & Lean concrete & 0.050 & \\
\hline & Hollow core concrete & 0.180 & \\
\hline & Lime/gypsum plaster & 0.020 & \\
\hline
\end{tabular}


In September 2017, two-sensors-Heat Cost Allocators (HCAs) and Thermostatic Radiator Valves (TRVs) -were installed on each radiator to comply with the EED obligation [16], transposed in Italy with the Legislative Decree 102/2014 and subsequent amendments and integrations [17]. To allow an optimal system operation, a variable speed circulation pump was installed in the central boiler room. Together with the HCAs and the TRVs, two temperature sensors were installed in the bedroom and in the living room of each dwelling, which are able to measure the daily average temperature of the room as an average of 24-h measurements with a 6-min acquisition frequency. Additionally, a main thermal energy meter was installed on the main distribution pipes downstream of the centralized boiler in order to measure the total energy consumption of the building.

The installed heating powers have been estimated through the dimensional method $[18,19]$, after mapping the dimensions of all radiators, which was also required as preliminary action for the purposes of programming the HCAs. In the context of a specific project, survey questionnaires have been administrated to the inhabitants of the investigated building and on-field informative meetings have been organized, aimed at designing a suitable feedback strategy to enhance end-user's awareness. In particular, the analysis of surveys allowed authors to collect specific information about behavioral features which have been also meaningful for the present analysis, such as the ability to use thermostatic valves and chrono thermostat, and their feeling about indoor temperature in the apartment [20].

Table 2 contains the data related to the calculated installed heating power and the number of inhabitants of each apartment of the building case study.

Table 2. Installed heating power and number of inhabitants of each dwelling.

\begin{tabular}{ccc}
\hline Dwelling Number & Installed Power [kW] & Number of Inhabitants \\
\hline 1C & 12.96 & 1 \\
2A & 10.17 & 2 \\
3B & 10.63 & 3 \\
4C & 9.78 & 2 \\
5A & 9.05 & 2 \\
6B & 8.67 & 7 \\
7C & 13.80 & 4 \\
8A & 11.53 & 1 \\
9B & 11.99 & 2 \\
\hline
\end{tabular}

\subsection{Simulation Model}

A dynamic simulation of the case-study building has been performed by the authors by means of the energy tool TRNSYS-17 [21], which allows to simulate the dynamic behavior multi-zone buildings and their systems. The software carries out the simulation basing on a thermal balance (typically on an hourly basis) taking into account the effects of the accumulation and of the thermal release of the opaque building envelope [22,23].

Both the building envelope and the heating system were modeled and simulated and the results were validated according to the real thermal energy measured at both the building level (through the main thermal energy meter) and at the dwelling level (by means of the data collected by the HCAs installed in the dwellings). The heating season 2017-2018 (approximately from November 1st to April 15 th) has been chosen as reference period for the validation.

The 3-D building-type model was developed through the Google SketchUp plug-in “Trnsys3d" [24], as shown in Figure 3, in which the thermo-physical properties associated to the building envelope are the ones collected in Table 1.

Due to technical reasons (in Trnsys3d thermal zones must be convex), 24 thermal zones have been used to model the apartments, namely: 3 for type $B$ and type $C$ dwellings and 2 for type A dwellings. For the attic, 8 thermal zones with pitched roof have been implemented. The stairwell has been represented with one thermal zone for each floor. 


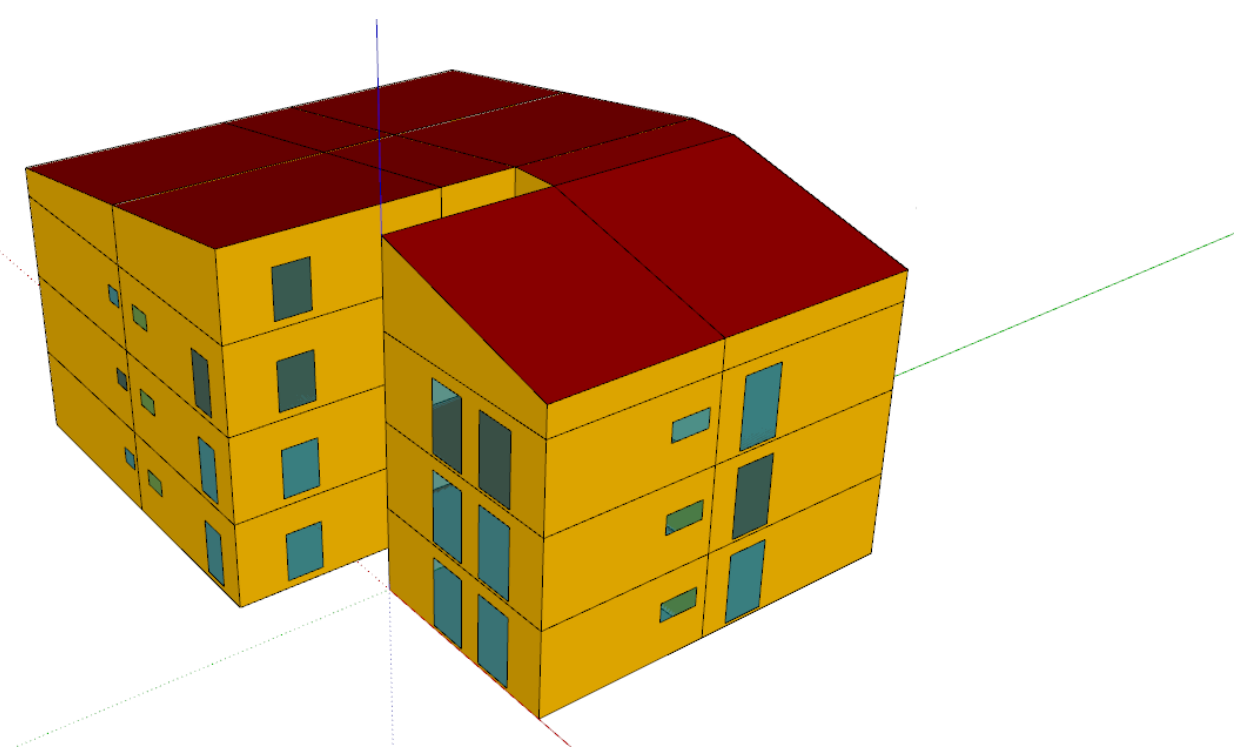

Figure 3. 3-D model of the building case-study.

The infiltration rate (i.e., the number of air volumes in the unit of time entering the building from the outside through the windows due to their inadequate closure) has been set according to the conventional values for residential buildings [25], which depend on air tightness but also on wind speed.

The only considered internal heat gain contribution was the one coming from the inhabitants, since most of the apartments are not equipped with highly energy-consuming electrical devices and only a few of the rooms are actually used by the inhabitants.

The heating system has been modeled as the summation of four components by means of specific system-types, accounting for: (i) the emission system, whose heating power represents an input and is given in Table 2; (ii) the generation system, whose efficiency is an input parameter and has been calculated as the average generation efficiency of two consecutive years measured during the experimental campaign (i.e., the ratio between the thermal energy consumption measured by the direct heat meter installed downstream to the boiler and the natural gas consumption expressed in $\mathrm{kWh}$ and measured by the building natural gas meter); (iii) the system circulators; (iv) distribution and mixing systems.

Given the presence of TRVs on the emission terminals, with which the inhabitants can adjust the indoor temperature of the rooms, a fluctuant set-point temperature has been associated to each thermal zone. This is represented by the average weekly value assumed by the mean temperature measured through the T-logger sensors installed in the dwellings. The operation of the generation system is controlled by a daily and a seasonal control schedule, simulated, respectively, according to the actual on-off schedule of the heating system (from 6 to 8 a.m. and from 15 to 22 p.m.) and to the heating period established according to the Italian law [26] for the reference climatic zone (climatic zone: D, heating degree-days (HDD): 1911, heating period: 1st November-15th April).

\section{Results and Discussion}

For each thermal zone, the heating demand was obtained for the base scenario, i.e., the simulation of the full operation of the building, where all apartments are heated with a fluctuating set-point temperature determined as the mean weekly temperature measured by the temperature sensors installed in the dwellings.

Figures 4-6 show the hourly distribution of the heating load for the analyzed dwellings obtained by the dynamic simulation, each representing a macro thermal-zone resulting from the summation of 
the thermal zones simulating the dwellings. For simplicity reasons, the graphs show only the heating season (i.e., from 1st January to 15th April, and from 1st November to 31st December).

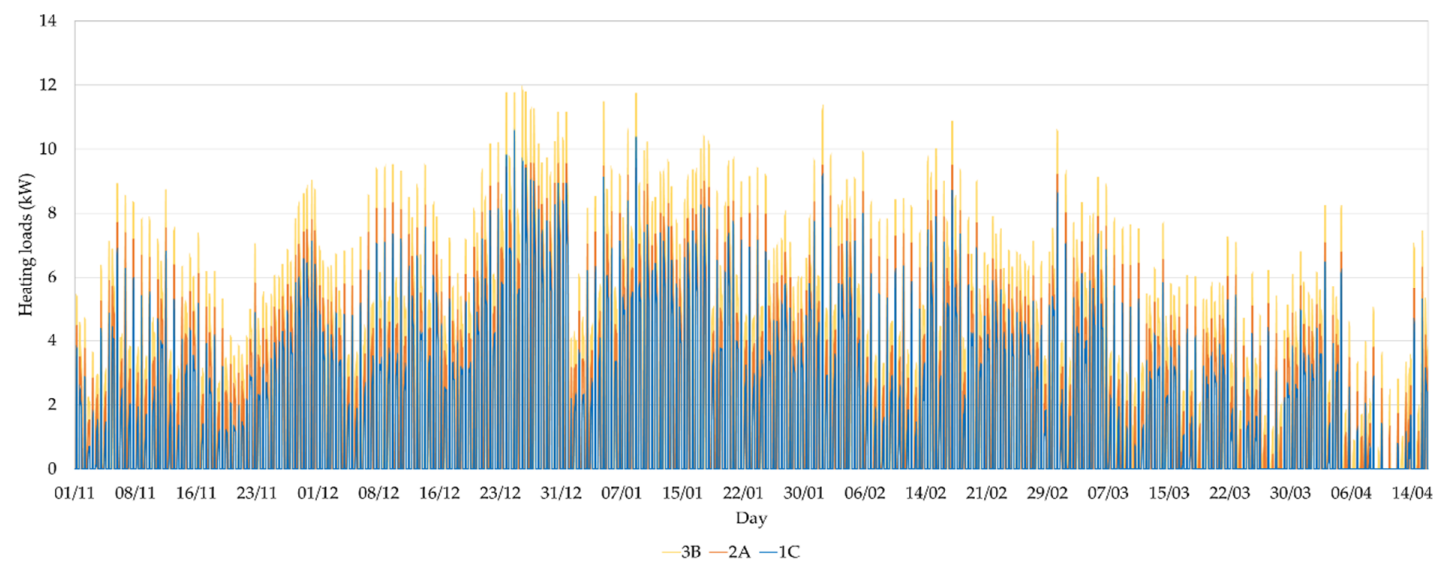

Figure 4. Simulated heating load of apartments 1C, 2A and 3B.

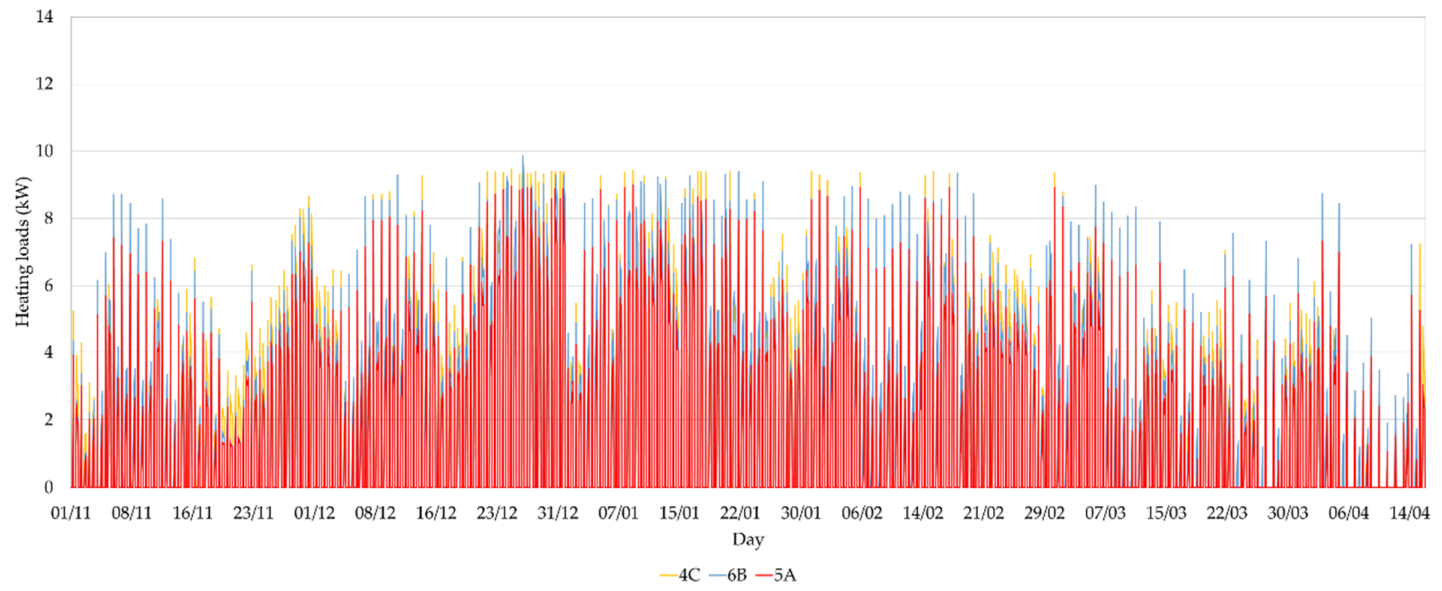

Figure 5. Simulated heating load of apartments $4 \mathrm{C}, 5 \mathrm{~A}$ and $6 \mathrm{~B}$.

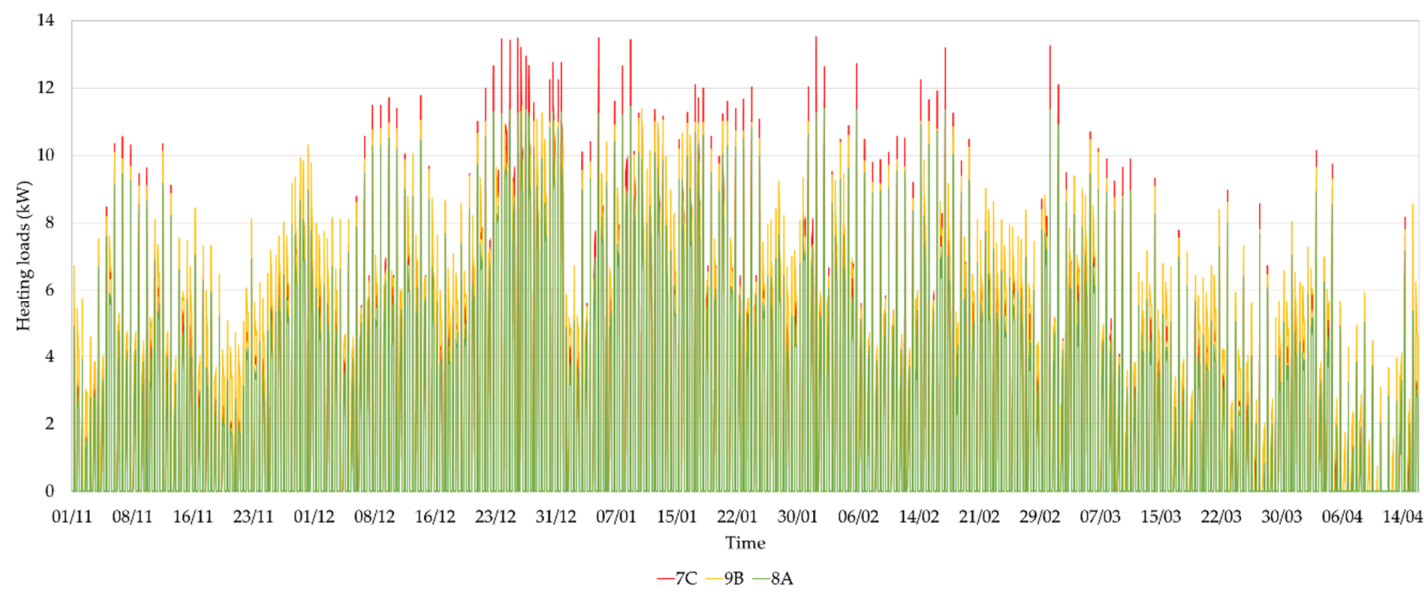

Figure 6. Simulated heating load of apartments 7C, 8A and 9B.

The annual heating consumption was calculated as the area below the power curve obtained by the simulation. Both the estimated and the measured energy consumptions were normalized with respect to the reference HDDs of the building location (1911) as reported by Equations (1) and (2).

$$
(\text { normalized consumption })_{\text {estimated }}=\frac{\text { estimated consumption }}{H D D_{(\text {weather file })}} \cdot 1911
$$




$$
\left(\text { normalized consumption }_{\text {measured }}=\frac{\text { measured consumption }}{H D D_{2017-18}} \cdot 1911\right.
$$

where $H D D_{\text {(weather file) }}$ are the HDDs calculated for the weather file used for the simulation and $H D D_{2017-18}$ are the HDDs of the heating season of 2017-2018 of the building location obtained by the local weather database.

A calibration of the model has been performed, aimed at decreasing the magnitude of the simulation error in some apartments. In fact, after the first simulation, apartments 5A, 6B, 7C and 8A showed the highest simulation errors (see Table 3). In this regard, information was retrieved by the authors in the field, during meetings specifically organized to collect data about end-user's behavior. In particular, it has been found that users of those apartments used to open their windows during the heating hours, instead of employing the TRVs, to decrease the indoor temperature. For this reason, for the above-mentioned apartments, a calibration has been performed by the authors by increasing the ventilation rate until the error decreased to a range of $\pm 15 \%$.

Table 3. Results of validation before and after the calibration process (respectively BC and AC).

\begin{tabular}{|c|c|c|c|c|c|}
\hline \multirow{2}{*}{ Dwelling Number } & \multirow{2}{*}{$\begin{array}{l}\text { Estimated Normalized Energy } \\
\text { Consumption, BC }[\mathrm{kWh}]\end{array}$} & \multirow{2}{*}{$\begin{array}{l}\text { Estimated Normalized Energy } \\
\text { Consumption, AC }[\mathrm{kWh}]\end{array}$} & \multirow{2}{*}{$\begin{array}{c}\text { Measured Normalized } \\
\text { Energy Consumption [kWh] }\end{array}$} & \multicolumn{2}{|c|}{ Error [\%] } \\
\hline & & & & BC & AC \\
\hline $1 C$ & 4918 & 5424 & 5673 & $-13 \%$ & $-4 \%$ \\
\hline $2 \mathrm{~A}$ & 6578 & 6847 & 6796 & $-3 \%$ & $1 \%$ \\
\hline $3 B$ & 7686 & 7704 & 7334 & $5 \%$ & $5 \%$ \\
\hline $4 \mathrm{C}$ & 6600 & 7351 & 7685 & $-14 \%$ & $-4 \%$ \\
\hline $5 \mathrm{~A}$ & 4552 & 5934 & 5578 & $-18 \%$ & $6 \%$ \\
\hline $6 \mathrm{~B}$ & 4470 & 7151 & 7386 & $-39 \%$ & $-3 \%$ \\
\hline $7 C$ & 5846 & 9015 & 9617 & $-39 \%$ & $-6 \%$ \\
\hline $8 \mathrm{~A}$ & 5206 & 7885 & 8919 & $-42 \%$ & $-12 \%$ \\
\hline $9 \mathrm{~B}$ & 8042 & 9882 & 9460 & $-15 \%$ & $4 \%$ \\
\hline TOTAL & 53897 & 67193 & 68449 & $-21 \%$ & $-2 \%$ \\
\hline
\end{tabular}

Results are reported in Table 3, namely: the normalized measured energy consumption of each dwelling for the heating season 2017-2018 (estimated basing on the reading of the HCAs); the normalized estimated energy consumption (i.e., obtained by means of the dynamic simulation implemented using TRNSYS17), respectively before and after the calibration process (BC and AC); the error between the estimated and the measured normalized thermal energy consumption before and after the calibration process (BC and $\mathrm{AC})$, calculated as per Equation (3).

$$
\text { error }[\%]=\frac{\text { estimated consumption }- \text { measured consumption }}{\text { measured consumption }} \cdot 100
$$

In Table 3, only the energy consumptions normalized with respect to the reference HDDs of the building location are reported.

As shown in Table 3, following the calibration process on dwellings 5A, 6B, 7C and 8A, the error calculated with respect to the total energy consumption of the building decreased to $-2 \%$, while the one of single dwellings decreased to a range of $+6 /-12 \%$. Thus, the validation results have been considered to be acceptable for the purpose of the present analysis.

Indeed, these small deviations may be caused by different causes, as following:

i potential differences between real and estimated thermal transmittances and thermal mass of the building;

ii for the purposes of the present analysis, the set-point temperature is set as average measured weekly temperature of the entire thermal zone;

iii the energy consumption of single dwellings is estimated based on HCAs readings, which depend also on the estimation of radiators' thermal output performed through the dimensional method described in $[18,19]$. It has been demonstrated that different installation conditions can lead 
to deviations between operating and standard radiators' thermal output in a range of about $5-15 \%$ [27].

The heat flowing through the adjacent wall ( $\left.Q_{h}[\mathrm{Wh}]\right)$ of two dwellings in one hour, $h$, has been calculated as per Equation (4):

$$
Q_{h}=U \cdot A \cdot\left(T_{\text {in }}-T_{\text {out }}\right) \cdot h
$$

where $\mathrm{U},\left[\mathrm{W} \mathrm{m} \mathrm{m}^{-2} \mathrm{~K}^{-1}\right]$ is the thermal transmittance of the wall, $\mathrm{A}\left[\mathrm{m}^{2}\right]$ is the area of the wall and $T_{\text {in }}-T_{\text {out }},[K]$ is the temperature difference between the inner and the outer layer of the wall (with $T_{\text {in }}$ indicating the temperature measured at the inner surface-i.e., the surface of the analyzed dwelling — while $T_{\text {out }}$ the outer surface temperature-i.e., the temperature of the adjacent dwelling).

The total heat stolen/given through each wall separating adjacent dwellings was calculated as per Equation (5).

$$
Q_{\text {stolen/given }}=\sum_{h=1}^{8760} Q_{h}
$$

In this way, the heat calculated as per Equations (4) and (5) is positive when the reference environment is gaining heat; on the contrary, it is negative when the heat is transferred from the reference environment to the adjacent one.

For each $i$-th apartment, the heat flowing through the walls adjacent with other apartments was calculated and it was assessed how much these heat flows would impact on the total energy consumption of the apartment itself as per Equation (6).

$$
\frac{Q_{\text {stolen } / \text { given }, i}}{Q_{\text {tot }, i}} \cdot 100
$$

\begin{tabular}{|c|c|c|c|c|c|c|c|c|c|c|}
\hline from & $1 C$ & $2 \mathrm{~A}$ & $3 B$ & $4 C$ & $5 \mathrm{~A}$ & $6 B$ & $7 \mathrm{C}$ & $8 \mathrm{~A}$ & $9 B$ & Total \\
\hline $1 C$ & & $\begin{array}{c}44 \\
(0.9 \%)\end{array}$ & & $\begin{array}{c}285 \\
(6.2 \%)\end{array}$ & & & & & & $\begin{array}{c}329 \mathrm{kWh} \\
(7.1 \%)\end{array}$ \\
\hline $2 \mathrm{~A}$ & $\begin{array}{c}-44 \\
(-0.7 \%)\end{array}$ & & $\begin{array}{c}2 \\
(0.0 \%)\end{array}$ & & $\begin{array}{c}18 \\
(0.3 \%)\end{array}$ & & & & & $\begin{array}{c}-23 \mathrm{kWh} \\
(-0.4 \%)\end{array}$ \\
\hline 3B & & $\begin{array}{c}-2 \\
(0.0 \%)\end{array}$ & & & & $\begin{array}{c}-46 \\
(-0.6 \%)\end{array}$ & & & & $\begin{array}{c}-49 \mathrm{kWh} \\
(-0.7 \%)\end{array}$ \\
\hline $4 C$ & $\begin{array}{c}-285 \\
(-4.6 \%) \\
\end{array}$ & & & & $\begin{array}{c}-29 \\
(-0.5 \%)\end{array}$ & & $\begin{array}{c}-323 \\
(-5.2 \%)\end{array}$ & & & $\begin{array}{c}-638 \text { kWh } \\
(-10.2 \%)\end{array}$ \\
\hline $5 \mathrm{~A}$ & & $\begin{array}{c}-18 \\
(-0.4 \%) \\
\end{array}$ & & $\begin{array}{c}29 \\
(0.6 \%) \\
\end{array}$ & & $\begin{array}{c}-13 \\
(-0.3 \%) \\
\end{array}$ & & $\begin{array}{c}-181 \\
(-3.6 \%) \\
\end{array}$ & & $\begin{array}{c}-183 \mathrm{kWh} \\
(-3.6 \%)\end{array}$ \\
\hline $6 B$ & & & $\begin{array}{c}46 \\
(0.8 \%)\end{array}$ & & $\begin{array}{c}13 \\
(0.2 \%)\end{array}$ & & & & $\begin{array}{c}148 \\
(2.4 \%)\end{array}$ & $\begin{array}{c}207 \mathrm{kWh} \\
(3.4 \%)\end{array}$ \\
\hline $7 C$ & & & & $\begin{array}{c}323 \\
(4.2 \%) \\
\end{array}$ & & & & $\begin{array}{c}5 \\
(0.1 \%) \\
\end{array}$ & & $\begin{array}{c}328 \mathrm{kWh} \\
(4.3 \%)\end{array}$ \\
\hline $8 \mathrm{~A}$ & & & & & $\begin{array}{c}181 \\
(2.7 \%)\end{array}$ & & $\begin{array}{c}-5 \\
(-0.1 \%)\end{array}$ & & $\begin{array}{c}86 \\
(1.3 \%)\end{array}$ & $\begin{array}{c}261 \quad \mathrm{kWh} \\
(3.9 \%)\end{array}$ \\
\hline $9 B$ & & & & & & $\begin{array}{c}-148 \\
(-1.8 \%)\end{array}$ & & $\begin{array}{c}-86 \\
(-1.0 \%)\end{array}$ & & $\begin{array}{c}-234 \mathrm{kWh} \\
(-2.8 \%)\end{array}$ \\
\hline
\end{tabular}

The results are reported for each apartment in Table 4 for the base scenario first.

Table 4. Percentage * of heat given or stolen between adjacent apartments, base scenario.

* to be read row by column, (-) signs meaning that the row apartment is giving energy to the column apartment; (+) signs meaning that the row apartment is stealing energy to the column apartment.

It is worth to observe that results obtained by this calculation depend both on the set-point temperature and the 'position' of the dwelling with respect to the others. For sake of completeness, a summary of the average seasonal value of the set-point temperature used to simulate the base scenario is given in Table 5 .

Generally speaking, results show that in case of full operation of the building, the phenomenon of heat-thefts is almost negligible, representing on average $0.5 \%$ of the annual energy consumption for heating purposes of a single dwelling with the maximum absolute value of $6.2 \%$. Observing the apartment with the lowest average set-point temperature (1C), it is possible to notice that this 
"steals heat" from both apartments $2 \mathrm{~A}$ and $4 \mathrm{C}$ (respectively $1.0 \%$ and $6.2 \%$ of its total energy need for space heating).

Table 5. Average seasonal values of set-point temperature used for the simulation of the base scenario.

\begin{tabular}{cc}
\hline Dwelling Number & $\begin{array}{c}\text { Set-Point Temperature, } \\
\text { Average Seasonal Values }\left[{ }^{\circ} \mathrm{C}\right]\end{array}$ \\
\hline 1C & 18.6 \\
2A & 20.5 \\
3B & 21.4 \\
4C & 20.4 \\
5A & 19.3 \\
6B & 19.6 \\
7C & 19.6 \\
8A & 19.5 \\
9B & 22.1 \\
\hline
\end{tabular}

On the other hand, even a central apartment that could benefit from its position (as for example apartment $4 \mathrm{C}$ ) can nullify this advantage when using set-point temperatures higher than the one of adjacent apartments, losing up to $10 \%$ of its energy need.

However, an unexpected behavior can be highlighted for apartments 2A, 5A and 8A. Although, in fact, apartment $5 \mathrm{~A}$ has set the lowest average set point temperature, it still gives heat to both adjacent apartments on the same vertical $(2 \mathrm{~A}$ and $8 \mathrm{~A})$. This is because set-point temperature is reached in the apartments only during the operating hours of the heating plant, while, for the rest of the day, the temperature inside the apartment $5 \mathrm{~A}$ is always higher than that in $8 \mathrm{~A}$ and $2 \mathrm{~A}$, due to its favorable position. This is evident in Figure 7, which reports the indoor temperature for the above-mentioned three apartments in a representative week of the heating season.

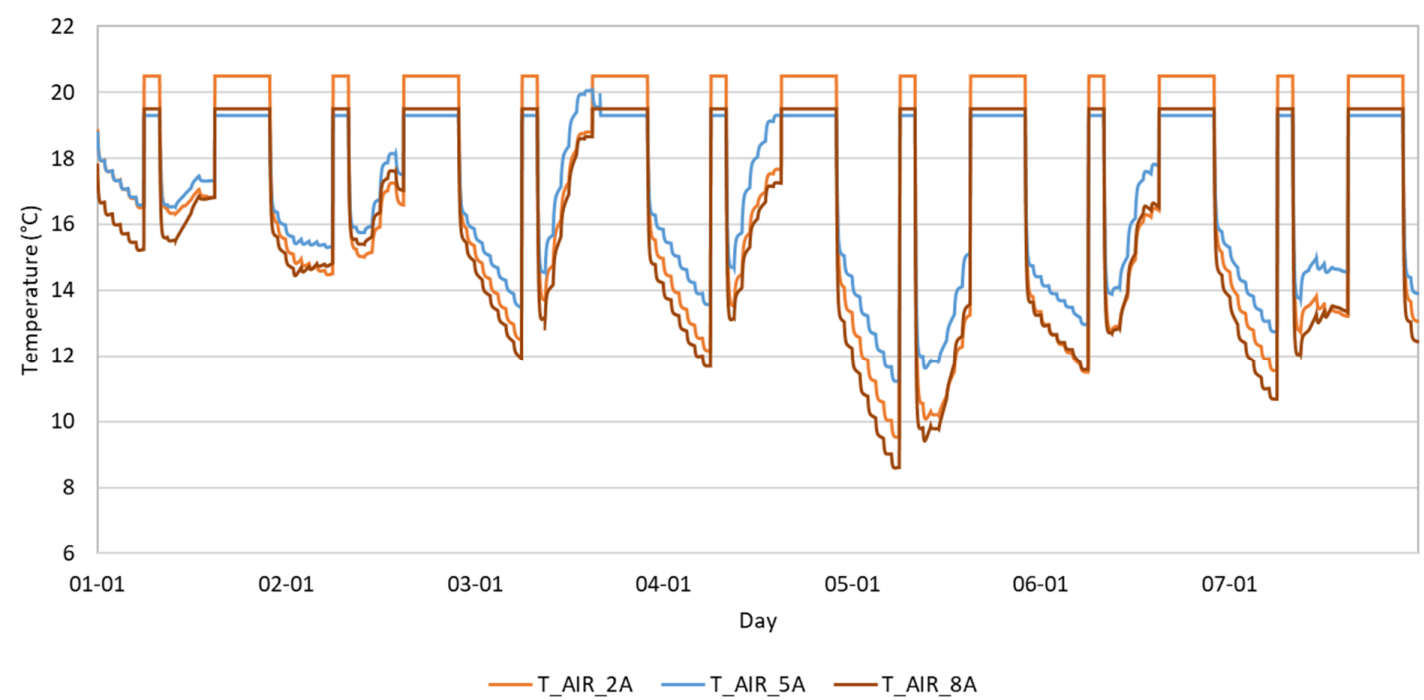

Figure 7. Simulated indoor temperature variation of apartments $2 \mathrm{~A}, 5 \mathrm{~A}$ and $8 \mathrm{~A}$ in a representative week of the heating season, base scenario.

Referring to Figure 7, it is highlighted that in a day there are two "heating periods", according to the schedule of the heating plant (from 6 to 8 a.m. and from 15 to 22 p.m.). From the figure, it is evident that the installed heating system quickly manages to bring the apartment up to the set-point temperature, even in situations of daily temperature excursions. For the sake of completeness, Figure $8 \mathrm{a}, \mathrm{b}$ show the trends of the daily indoor temperature in the above-mentioned apartments during the warm-up times simulated for January the 5th, which is representative of a cold winter day. From the figure, it can be highlighted that, even under high load conditions (i.e., low outdoor temperature), the heating system 
is very effective and set-point temperatures are reached in less than about $15 \mathrm{~min}$. Generally speaking, this limited warm-up time mainly depends on the time constant of the heating system and, to a lesser extent, on that of the building. Obviously, this heating transient is not representative of the indoor comfort conditions of the room, that are determined by both the indoor air temperature and the mean radiant temperature, which depends on the thermal mass of the building.

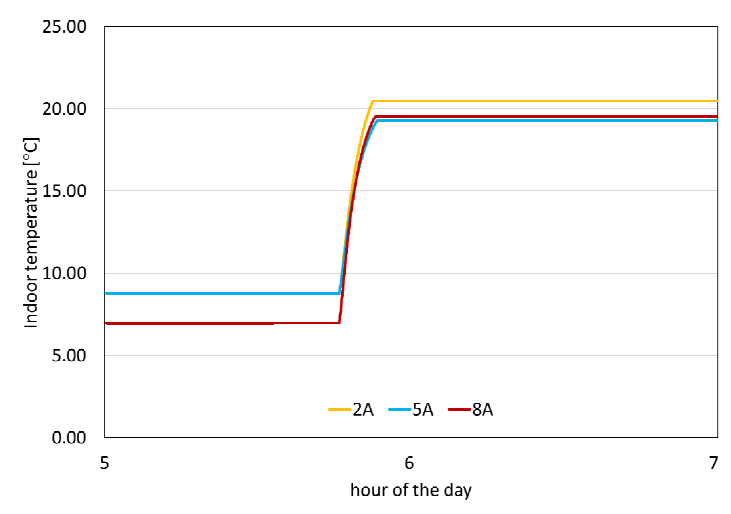

(a)

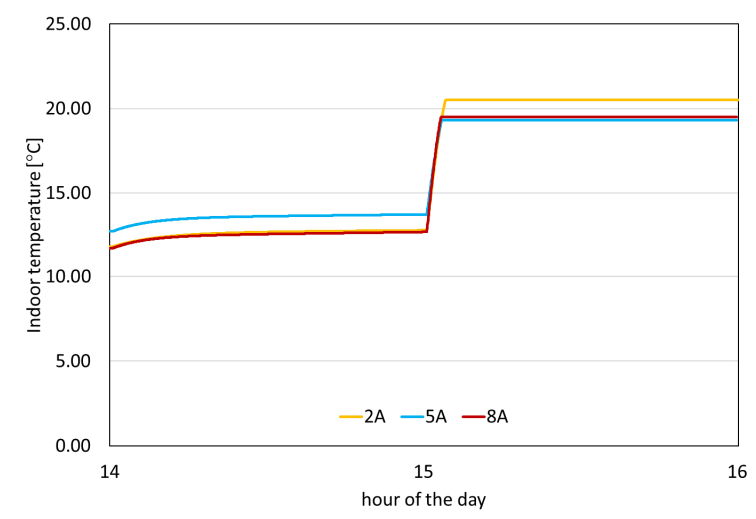

(b)

Figure 8. Simulated indoor temperature trends of apartments $2 \mathrm{~A}, 5 \mathrm{~A}$ and $8 \mathrm{~A}$ during the warm-up time of a representative day: (a) from 5:00 a.m. to 7:00 a.m.; (b) from 14:00 p.m.to 16:00 p.m.

On the other hand, the low thermal mass of the building is the cause of high temperature drops when the generator is turned off, especially in apartments in disadvantaged positions, despite their heat thefts from adjacent dwellings. Finally, it is worth to observe the behavior of the building during non-heating hours with the related heat exchanges among apartments.

For the purpose of evaluating the heat gains and losses due to a change of operation, the authors simulated two different scenarios in addition to the base one: (i) scenario a, in which only apartment $5 \mathrm{~A}$ was assumed to be unheated; (ii) scenario $\mathrm{b}$, in which only apartment $2 \mathrm{~A}$ was assumed to be unheated. In both cases, the set-point temperatures of all other apartments remained unchanged with respect to the base scenario. These were chosen as representative of the most and the least favored positions of block A (but similar considerations can be made for block B except for minor changes due to the different orientation): in fact, apartment $5 \mathrm{~A}$ is located in the second floor and surrounded by heated spaces (apartments 2A, 6B, 4C and 8A) while apartment $2 \mathrm{~A}$ is located at the first floor and its uninsulated floor is completely exposed to outdoor temperature.

Table 6 shows the results obtained from switching off the heating system of the dwelling $5 \mathrm{~A}$ (scenario a).

Obviously, in this case all the thermal zones adjacent to apartment 5A give energy to it, with apartment $2 \mathrm{~A}$ and $8 \mathrm{~A}$ giving, respectively, $8.5 \%$ and $5.2 \%$ of their total energy need for space heating (in fact these apartments have the largest heat exchange surfaces). Overall, apartment $5 \mathrm{~A}$ is able to steal $1249 \mathrm{kWh}$ from its neighbors, which would have accounted for $25 \%$ of its energy consumption in the base scenario.

Referring to Figure 9, it is important to highlight that when the heating system is not working, in some hours of the week, apartment $5 \mathrm{~A}$ still has its indoor air temperature higher than the one of both adjacent dwellings, confirming again the existence of an inversion in the direction of the heat flows already highlighted in the base scenario. In this scenario, the average seasonal difference of indoor temperature between apartment $5 \mathrm{~A}$ and the other heated apartment is about $2.6^{\circ} \mathrm{C}$. Table 7 shows the results obtained from switching off the heating system of the dwelling $2 \mathrm{~A}$ (scenario $\mathrm{b}$ ) while Figure 10 shows the trend of the indoor temperature of the investigated apartments in a representative week of the heating season. 
Table 6. Percentage * of heat given or stolen between adjacent apartments, scenario a, kWh and (\%).

\begin{tabular}{|c|c|c|c|c|c|c|c|c|c|c|}
\hline from to & 1C & $2 \mathrm{~A}$ & 3B & $4 C$ & $5 \mathrm{~A}$ & $6 \mathrm{~B}$ & $7 \mathrm{C}$ & $8 \mathrm{~A}$ & 9B & Total \\
\hline $1 \mathrm{C}$ & & $\begin{array}{c}25 \\
(0.5 \%)\end{array}$ & & $\begin{array}{c}265 \\
(5.7 \%)\end{array}$ & & & & & & $\begin{array}{c}290 \mathrm{kWh} \\
(6.2 \%)\end{array}$ \\
\hline $2 \mathrm{~A}$ & $\begin{array}{c}-25 \\
(-0.4 \%)\end{array}$ & & $\begin{array}{c}19 \\
(0.3 \%)\end{array}$ & & $\begin{array}{c}-520 \\
(-8.5 \%)\end{array}$ & & & & & $\begin{array}{c}-526 \mathrm{kWh} \\
(-8.6 \%)\end{array}$ \\
\hline 3B & & $\begin{array}{c}-19 \\
(-0.3 \%)\end{array}$ & & & & $\begin{array}{c}-65 \\
(-0.9 \%)\end{array}$ & & & & $\begin{array}{c}-85 \mathrm{kWh} \\
(-1.2 \%)\end{array}$ \\
\hline $4 C$ & $\begin{array}{c}-265 \\
(-4.2 \%)\end{array}$ & & & & $\begin{array}{c}-208 \\
(-3.3 \%)\end{array}$ & & $\begin{array}{c}-303 \\
(-4.7 \%)\end{array}$ & & & $\begin{array}{c}-776 \quad \mathrm{kWh} \\
(-12.2 \%)\end{array}$ \\
\hline $5 \mathrm{~A}$ & & $\begin{array}{l}520 \\
\text { (n.a.) }\end{array}$ & & $\begin{array}{l}208 \\
\text { (n.a.) }\end{array}$ & & $\begin{array}{l}156 \\
\text { (n.a.) }\end{array}$ & & $\begin{array}{c}364 \\
\text { (n.a.) }\end{array}$ & & $\begin{array}{l}1249 \text { kWh } \\
\text { (n.a.) }\end{array}$ \\
\hline 6B & & & $\begin{array}{c}65 \\
(1.1 \%)\end{array}$ & & $\begin{array}{c}-156 \\
(-2.5 \%)\end{array}$ & & & & $\begin{array}{c}165 \\
(2.6 \%) \\
\end{array}$ & $\begin{array}{cc}74 \quad \mathrm{kWh} \\
(1.2 \%)\end{array}$ \\
\hline $7 \mathrm{C}$ & & & & $\begin{array}{c}303 \\
(3.9 \%)\end{array}$ & & & & $\begin{array}{c}-13 \\
(-0.2 \%)\end{array}$ & & $\begin{array}{c}290 \mathrm{kWh} \\
(3.8 \%)\end{array}$ \\
\hline $8 \mathrm{~A}$ & & & & & $\begin{array}{c}-364 \\
(-5.2 \%)\end{array}$ & & $\begin{array}{c}13 \\
(0.2 \%)\end{array}$ & & $\begin{array}{c}101 \\
(1.4 \%) \\
\end{array}$ & $\begin{array}{c}-250 \quad \mathrm{kWh} \\
(-3.6 \%)\end{array}$ \\
\hline 9B & & & & & & $\begin{array}{c}-165 \\
(-1.9 \%)\end{array}$ & & $\begin{array}{c}-101 \\
(-1.2 \%)\end{array}$ & & $\begin{array}{c}-266 \mathrm{kWh} \\
(-3.1 \%)\end{array}$ \\
\hline
\end{tabular}

* to be read row by column, (-) signs meaning that the row apartment is giving energy to the column apartment; $(+)$ signs meaning that the row apartment is stealing energy to the column apartment.

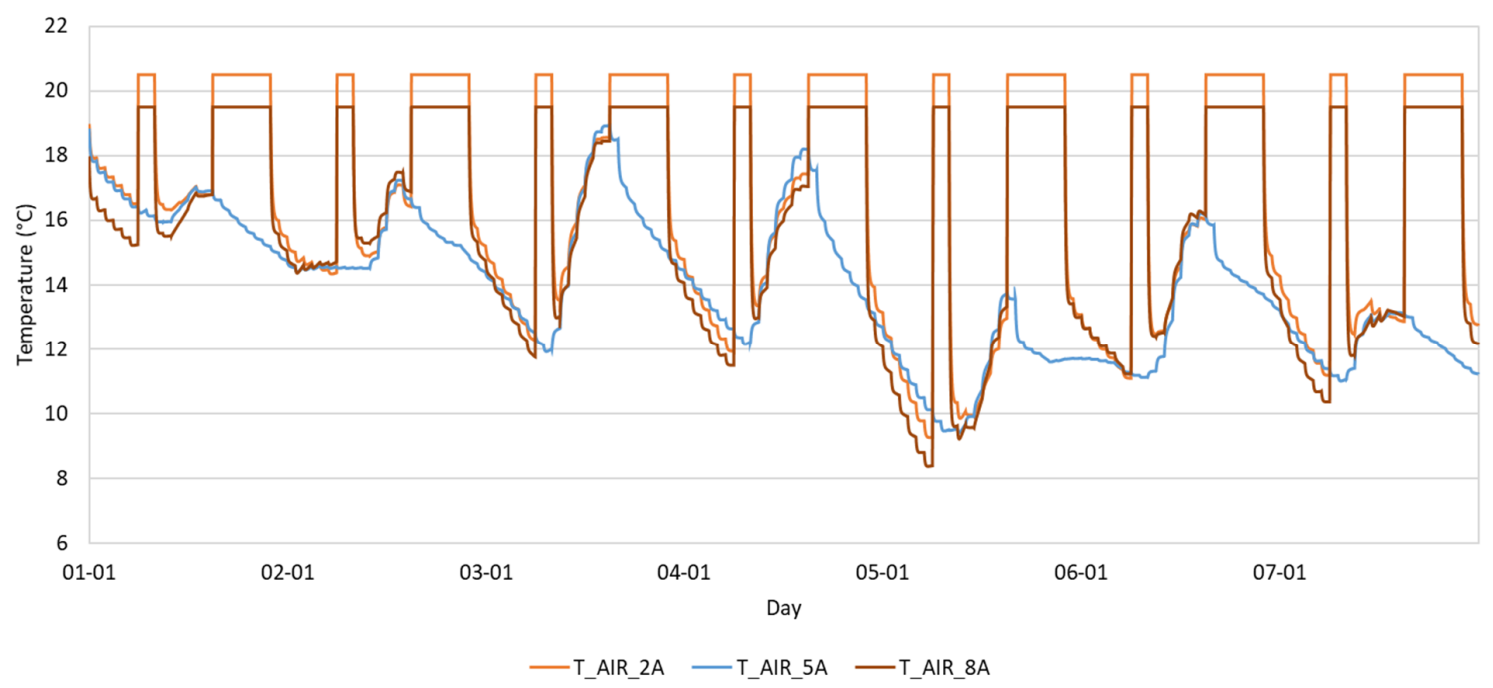

Figure 9. Indoor temperature variation of apartments $2 \mathrm{~A}, 5 \mathrm{~A}$ and $8 \mathrm{~A}$ in a representative week of the heating season, scenario a.

The results show that apartment $2 \mathrm{~A}$ is always able to gain heat from its neighbors (apartments $5 \mathrm{~A}, 1 \mathrm{C}, 3 \mathrm{~B}$,) since its indoor temperature is always lower than that of the other ones, stealing up to $13.6 \%$ of the total energy need for space heating of apartment $5 \mathrm{~A}$. Overall, apartment $2 \mathrm{~A}$ is able to steal $1160 \mathrm{kWh}$ from its neighbors, which would have accounted for $20 \%$ of its energy consumption in the base scenario. However, in this scenario, the average seasonal difference of indoor temperature between apartment $2 \mathrm{~A}$ and the other heated apartment is about $3.6^{\circ} \mathrm{C}$, which is $1.0^{\circ} \mathrm{C}$ lower than the one of apartment $5 \mathrm{~A}$ in the similar scenario.

From the analysis of the results it can be observed that heat transfer between a heated dwelling toward an adjacent unheated, ranges $20-25 \%$ of its theoretical energy need, which is much lower than the estimated $70-90 \%$ in available literature $[10,12,13]$. This is essentially due to the fact that the investigated building is poorly insulated (i.e., low thermal insulation both in the internal partitioning walls and towards the external environment); thus, the energy need of dwellings is mainly determined by their thermal dispersion towards the outdoor environment (compared to which the heat transfers toward other apartments are certainly lower). On the contrary, in [8-10,12,13] the investigated case-study buildings presented highly insulated external facades and they were mainly located in cold continental climates. The milder climatic conditions under which the present simulation has been 
carried out also affect the extent of heat stolen, thanks to not-negligible solar heat gains, which in scenario a determine an inversion of heat exchanges during the central hours of sunny days.

Table 7. Share * of heat given or stolen between adjacent apartments, scenario $\mathrm{b}, \mathrm{kWh}$ and (\%).

\begin{tabular}{|c|c|c|c|c|c|c|c|c|c|c|}
\hline from & $1 C$ & $2 \mathrm{~A}$ & 3B & $4 C$ & $5 \mathrm{~A}$ & 6B & 7C & $8 \mathrm{~A}$ & $9 B$ & Total \\
\hline $1 \mathrm{C}$ & & $\begin{array}{c}-193 \\
(-4.0 \%)\end{array}$ & & $\begin{array}{c}315 \\
(6.6 \%)\end{array}$ & & & & & & $\begin{array}{c}122 \mathrm{kWh} \\
(2.6 \%)\end{array}$ \\
\hline $2 \mathrm{~A}$ & $\begin{array}{c}193 \\
\text { (n.a.) }\end{array}$ & & $\begin{array}{c}228 \\
\text { (n.a.) } \\
\end{array}$ & & $\begin{array}{c}739 \\
\text { (n.a.) }\end{array}$ & & & & & $\begin{array}{c}1160 \text { kWh } \\
\text { (n.a.) }\end{array}$ \\
\hline $3 B$ & & $\begin{array}{c}-228 \\
(-3.1 \%)\end{array}$ & & & & $\begin{array}{c}-21 \\
(-0.3 \%)\end{array}$ & & & & $\begin{array}{c}-249 \mathrm{kWh} \\
(-3.4 \%)\end{array}$ \\
\hline $4 C$ & $\begin{array}{c}-315 \\
(-5.0 \%)\end{array}$ & & & & $\begin{array}{c}-54 \\
(-0.9 \%)\end{array}$ & & $\begin{array}{c}-317 \\
(-5.0 \%)\end{array}$ & & & $\begin{array}{cc}-686 & k W h \\
(-10.9 \%)\end{array}$ \\
\hline $5 \mathrm{~A}$ & & $\begin{array}{c}-739 \\
(-13.6 \%)\end{array}$ & & $\begin{array}{c}54 \\
(1.0 \%)\end{array}$ & & $\begin{array}{c}10 \\
(0.2 \%)\end{array}$ & & $\begin{array}{c}-107 \\
(-2.0 \%)\end{array}$ & & $\begin{array}{c}-782 \mathrm{kWh} \\
(-14.5 \%)\end{array}$ \\
\hline 6B & & & $\begin{array}{c}21 \\
(0.3 \%) \\
\end{array}$ & & $\begin{array}{c}-10 \\
(-0.2 \%)\end{array}$ & & & & $\begin{array}{c}153 \\
(2.5 \%) \\
\end{array}$ & $\begin{array}{c}164 \mathrm{kWh} \\
(2.7 \%)\end{array}$ \\
\hline $7 C$ & & & & $\begin{array}{c}317 \\
(4.1 \%)\end{array}$ & & & & $\begin{array}{c}2 \\
(0.0 \%)\end{array}$ & & $\begin{array}{c}319 \mathrm{kWh} \\
(4.1 \%)\end{array}$ \\
\hline $8 \mathrm{~A}$ & & & & & $\begin{array}{c}107 \\
(1.6 \%)\end{array}$ & & $\begin{array}{c}-2 \\
(0.0 \%)\end{array}$ & & $\begin{array}{c}87 \\
(1.3 \%) \\
\end{array}$ & $\begin{array}{c}193 \mathrm{kWh} \\
(2.8 \%)\end{array}$ \\
\hline 9B & & & & & & $\begin{array}{c}-153 \\
(-1.8 \%)\end{array}$ & & $\begin{array}{c}-87 \\
(-1.0 \%)\end{array}$ & & $\begin{array}{c}-240 \quad \mathrm{kWh} \\
(-2.8 \%)\end{array}$ \\
\hline
\end{tabular}

* to be read row by column, (-) signs meaning that the row apartment is giving energy to the column apartment; $(+)$ signs meaning that the row apartment is stealing energy to the column apartment.

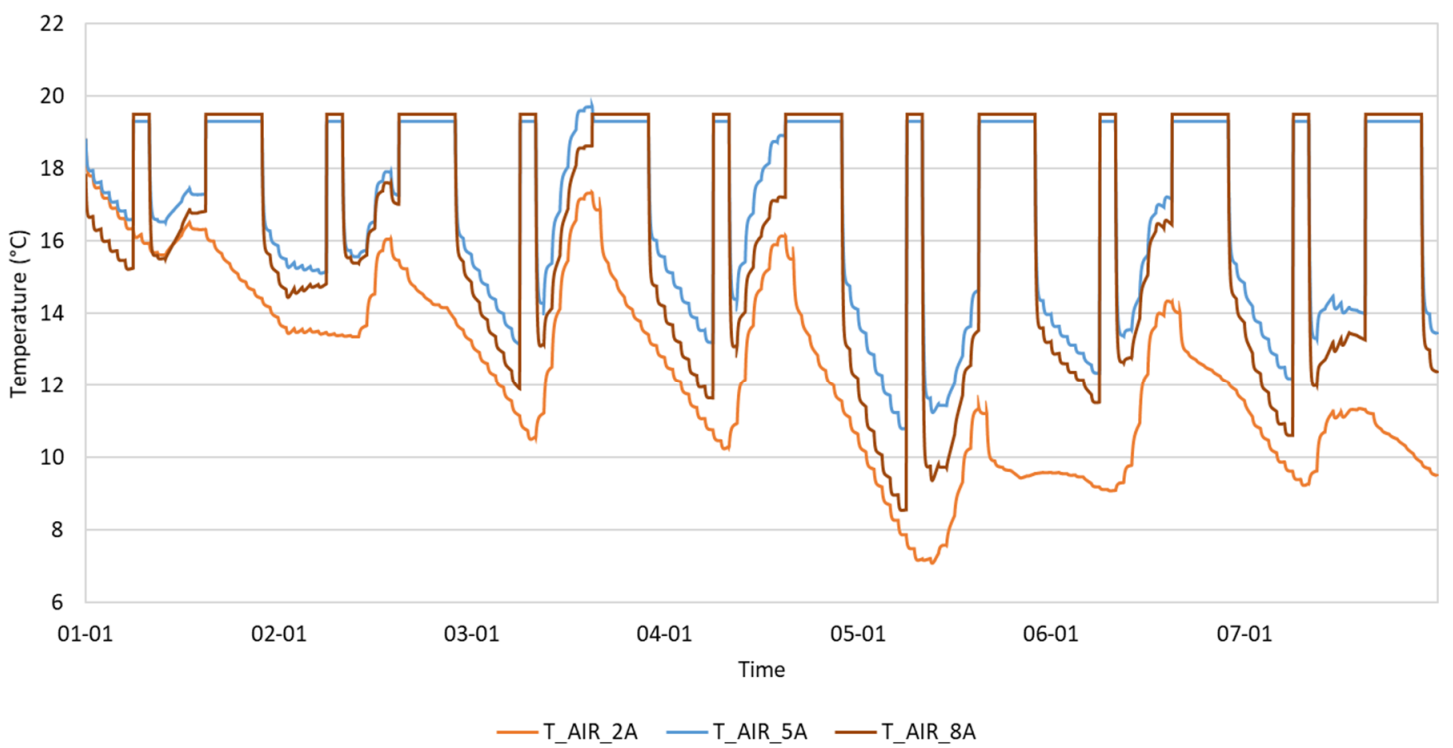

Figure 10. Indoor temperature variation of apartments $2 \mathrm{~A}, 5 \mathrm{~A}$ and $8 \mathrm{~A}$ in a representative week of the heating season, scenario $b$.

As a matter of fact, in a Mediterranean climate, the compensation of heat costs based on average indoor temperature [7-9] or on static heat flows [11], would tend to overestimate the stolen heat between apartments, not taking into consideration the dynamic behavior of this phenomenon. It is highlighted that the results obtained within the present research could be useful to analyze similar buildings in terms of climatic conditions and orientation. However, in order to allow a greater and general applicability of the results, it would be necessary to carry out a dedicated sensitivity analysis to the variation of the abovementioned parameters.

\section{Conclusions}

In this work the issue of heat thefts between adjacent apartments has been investigated by performing a dynamic simulation on a case-study building. To this end, a dynamic model of a real social housing building supplied by a centralized heating plant has been implemented using TRNSYS 
simulation software, validated with real energy consumption data and calibrated in order to obtain a maximum deviation from the measured data in a range of $+6 /-12 \%$ per apartment. The final estimation error of the model on the total building energy consumption was $-2 \%$.

Three scenarios were simulated, in order to highlight the differences between the possible operation of some apartments: a base scenario considering a full operation of the heating plant (i.e., all apartments heated at different set-point temperatures) and two additional scenarios in which two apartments chosen as representative of favorable and unfavorable positions were considered, individually, unheated.

The analysis highlighted that the amount of the heat thefts due to different set-point temperatures in case of full operation of the building is almost negligible in low-insulated buildings, such as the analyzed one. In particular, the share of heat exchanges calculated with respect to the total annual energy need for space heating of single apartments varies between 0 and $6.2 \%$. Dynamic effects of inversion of the heat transfers between adjacent apartments have also been highlighted in the same scenario when an intermediate floor apartment, although having a lower set-point temperature during the heating hours, registered a higher indoor temperature compared to when the heating system was not working.

It has also been highlighted that, for the same end-user behavior (i.e., switching off the heating system), the benefit obtained from the favorably positioned apartment is higher to that of the apartment located in a disadvantaged position in terms of indoor temperature, although the amount of heat thefts of the apartment with a disadvantaged position is higher.

In fact, depending on apartment location, the thermal mass of the apartments in a favorable position would prevent their indoor temperatures from falling below acceptable threshold values if the users of those dwellings decide to turn down their radiators through the TRVs. On the contrary, this would not be true for apartments in unfavorable positions.

The results obtained show that greater attention should be paid to heat thefts for the purpose of heat cost allocation, especially in buildings with occasional and uneven occupation and/or operation and in buildings with low thermal performances (in particular those with poorly insulated partition surfaces between apartments).

More attention should be given to the heat theft phenomenon both in terms of: (i) design of new buildings or of retrofit interventions. The building envelope and the heating system should be designed keeping in mind the real operating conditions while normally, in design phase, the apartments are considered to be always heated, even in buildings (such as mountain residences) normally employed for occasional occupation; (ii) development of specific compensation techniques for heat cost allocation in buildings with particular reference to the estimation of the "involuntary" part of energy consumption (i.e., the one which is not determined by the end-user behavior). Moreover, this study highlights the need of an extensive analysis regarding compensation due to heat transfers between adjacent apartments in mild climatic conditions, which is still required to obtain a heat cost allocation methodology easily replicable for designers and building managers.

Author Contributions: Conceptualization M.D., G.P.; methodology, M.D., G.F., L.C.; formal analysis, L.C., V.B.; investigation, L.C., V.B.; resources, M.D., G.P.; data curation, L.C., V.B.; writing-original draft preparation, L.C.; writing-review and editing, L.C., G.F., M.D., V.B., G.P.; supervision, G.F., M.D., G.P. All authors have read and agreed to the published version of the manuscript.

Funding: This work has been developed under the projects "Ricerca di Sistema Elettrico PAR 2016" funded by ENEA (grant number I12F16000180001) and "PRIN Riqualificazione del parco edilizio esistente in ottica NZEB" funded by MIUR (grant number 2015S7E247_002). The authors wish to thank ATER of Frosinone, the Territorial Agency for Social Housing, for the technical support during the on field experimental campaign.

Conflicts of Interest: The authors declare no conflict of interest 


\section{References}

1. European Union. Energy Roadmap. 2050. Available online: https://ec.europa.eu/energy/sites/ener/files/ documents/2012_energy_roadmap_2050_en_0.pdf (accessed on 1 February 2020).

2. International Energy Agency. Energy Efficiency: Buildings. The Global Exchange for Energy Efficiency Policies, Data and Analysis. Available online: https:/www.iea.org/topics/energyefficiency/buildings/ (accessed on 1 August 2019).

3. European Commission. Guidance Note on Directive 2012/27/EU on Energy Efficiency, Amending Directives 2009/125/EC and 2010/30/EC, and Repealing Directives 2004/8/EC and 2006/32/EC Article 7: Energy Efficiency Obligation Schemes Accompanying the Document Communication from the Commission to the European Parliament and the Council Implementing the Energy Efficiency Directive-Commission Guidance; European Commission: Brussels, Belgium, 2013.

4. European Commission. Directive (EU) 2018/844 of the European Parliament and of the Council of 30 May 2018 Amending Directive 2010/31/EU on the Energy Performance of Buildings and Directive 2012/27/EU on Energy Efficiency; European Commission: Brussels, Belgium, 2018.

5. Canale, L.; Dell'Isola, M.; Ficco, G.; Cholewa, T.; Siggelsten, S.; Balen, I. A comprehensive review on heat accounting and cost allocation in residential buildings in EU. Energy Build. 2019, 202. [CrossRef]

6. Dell'Isola, M.; Ficco, G.; Canale, L.; Frattolillo, A.; Bertini, I. A new heat cost allocation method for social housing. Energy Build. 2018, 172, 67-77. [CrossRef]

7. Liu, L.B.; Fu, L.; Jiang, Y.; Guo, S. Major issues and solutions in the heat-metering reform in China. Renew. Sustain. Energy Rev. 2011, 15, 673-680. [CrossRef]

8. Siggelsten, S. Reallocation of heating costs due to heat transfer between adjacent apartments. Energy Build. 2014, 75, 256-263. [CrossRef]

9. Michnikowski, P. Allocation of heating costs with consideration to energy transfer from adjacent apartments. Energy Build. 2017, 139, 224-231. [CrossRef]

10. Gafsi, A.; Lefebvre, G. Stolen heating or cooling energy evaluation in collective buildings using model inversion techniques. Energy Build. 2003, 35, 293-303. [CrossRef]

11. Pakanen, J.; Karjalainen, S. Estimating static heat flows in buildings for energy allocation systems. Energy Build. 2006, 38, 1044-1052. [CrossRef]

12. Lukić, N.; Nikolić, N.; Timotijević, S.; Tasić, S. Influence of an unheated apartment on the heating consumption of residential building considering current regulations-Case of Serbia. Energy Build. 2017, 155, 16-24. [CrossRef]

13. Xue, P.; Yang, F.; Zhang, Y.; Zhao, M.; Xie, J.; Liu, J. Quantitative study on adjacent room heat transfer: Heating load and influencing factors. Sustain. Cities Soc. 2019, 51, 101720. [CrossRef]

14. Siggelsten, S. Heat cost allocation in energy efficient multi-apartment buildings. Cogent Eng. $2018,5$. [CrossRef]

15. Italian National Unification. UNI 10200. Impianti Termici Centralizzati di Climatizzazione Invernale ed Acqua Calda Sanitaria-Criteri di Ripartizione Delle Spese di Climatizzazione ed Acqua Calda Sanitaria (in Italian Language Only); UNI: Milan, Italy, 2018.

16. European Commission. Directive 2012/27/EU of the European Parliament and of the Council of 25 October 2012 on Energy Efficiency, Amending Directives 2009/125/EC and 2010/30/EU and Repealing Directives 2004/8/EC and 2006/32/EC Text with EEA Relevance; European Commission: Brussels, Belgium, 2012.

17. Italian Republic. Decreto Legislativo 4 Luglio 2014, n. 102 Attuazione Della Direttiva 2012/27/UE Sull'efficienza Energetica, che Modifica le Direttive 2009/125/CE e 2010/30/UE e Abroga le Direttive 2004/8/CE e 2006/32/CE (in Italian Language Only); Gazzetta Ufficiale della Repubblica Italiana: Rome, Italy, 2014.

18. European Committee for Standardization (CEN). EN 442-1: Radiators and Convectors_Part 1: Technical Specification and Requirements; CEN: Brussels, Belgium, 2014.

19. European Committee for Standardization (CEN). EN 442-2: Radiators and Convectors_Part 2: Test Methods and Rating; CEN: Brussels, Belgium, 2014.

20. Dell'Isola, M.; Ficco, G.; Canale, L.; Palella, B.I.; Puglisi, G. An IoT Integrated Tool to Enhance User Awareness on Energy Consumption in Residential Buildings. Atmosphere 2019, 10, 743. [CrossRef]

21. University of Wisconsin. TRNSYS 17: A transien system simulation program. Sol. Energy Lab. 2012. Available online: http://www.trnsys.com/ (accessed on 19 July 2019). 
22. Attia, S.; Beltrán, L.; Herde, A.D.; Hensen, J. Architect friendly: A comparison of ten different building performance simulation tools. In Proceedings of the 11th International Building Performance Simulation Association Conference and Exhibition 2009, Glasgow, Scotland, 27-30 July 2009; pp. 204-211.

23. Crawley, D.B.; Hand, J.W.; Kummert, M.; Griffith, B.T. Contrasting the capabilities of building energy performance simulation programs. Build. Environ. 2006, 43. [CrossRef]

24. University of Wisconsin-Madison. TRNSYS 17 documentation, Volume 5, Multi zone building modeling with type56 and TRNBuild. Sol. Energy Lab. 2012.

25. Ente Nazionale Italiano di Unificazione. UNI 11300-1 Prestazioni Energetiche Degli Edifici-Parte 1: Determinazione del Fabbisogno di Energia Termica Dell'edificio per la Climatizzazione Estiva ed Invernale (in Italian); Ente Nazionale Italiano di Unificazione: Milano, Italy, 2014.

26. Italian Republic. Decreto del Presidente della Repubblica 26 Agosto 1993, n. 412 Regolamento Recante Norme per la Progettazione, L'installazione, L'esercizio e la Manutenzione Degli Impianti Termici Degli Edifici ai Fini del Contenimento dei Consumi di Energia, in Attuazione Dell'art. 4, Comma 4, Della Legge 9 Gennaio 1991, n. 10. (GU Serie Generale n.242 del 14-10-1993-Suppl. Ordinario n. 96); Gazzetta Ufficiale della Repubblica Italiana: Rome, Italy, 1993.

27. Arpino, F.; Cortellessa, G.; Dell'Isola, M.; Ficco, G.; Marchesi, R.; Tarini, C. Influence of installation conditions on heating bodies thermal output: Preliminary experimental results. Enrgy Procedia 2016, 101, 74-80. [CrossRef]

(C) 2020 by the authors. Licensee MDPI, Basel, Switzerland. This article is an open access article distributed under the terms and conditions of the Creative Commons Attribution (CC BY) license (http://creativecommons.org/licenses/by/4.0/). 